order of $10: 1$ improves the acuity by one line on the Snellen chart. The effect is rather less for observers with good vision than for those with poor vision, especially for high levels of illumination. However, the result is probably a useful working rule. There were some deviations from the general rule by some subjects, which are not shown by the averaged curves, but there is evidence that the errors were probably experimental and not systematic.

The data would suggest that it is necessary to set some standard of illumination of the Snellen chart, especially when this is used as a pass test of visual acuity for entrants to a trade or profession. The investigation was not, of course, concerned with the optimum level of illumination for clinical practice, although it would be of interest to know the range of illumination levels within which clinicians would normally work. A survey of clinical practice was made in 1928 in the U.S.A., ${ }^{*}$ but no recent surveys appear to have been made in this country. It is realised that for visual examinations conducted under unfavourable conditions of working, the clinician often finds it impossible to obtain the desired standard of lighting. The results of this study will, however, indicate to him the allowance which should be made for such deficiencies in illumination.

The investigation is part of the research programme of the Building Research Board of the Department of Scientific and Industrial Research, and this note is published by permission of the Director of Building Research. The authors would like to acknowledge the help of their colleagues who assisted in the experimental work.

\title{
THE FORMATION OF THE INTRA-OCULAR FLUIDS. STUDIES OF THE UREA COMPONENT OF THE AQUEOUS HUMOUR
}

BY

\author{
E. J. Ross
}

From the Department of Physiology, University College, and the Ophthalmological Research Unit M.R.C., Institute of Ophthalmology, London

IT has long been established that the concentration of urea in the aqueous humour is less than that in the blood plasma. After making allowance for the 7 per cent. difference in protein content between aqueous humour and plasma, the ratio of the urea concentrations of these two fluids has been determined by various workers using different chemical methods as follows :-

* R. S. BURNAP and E. C. JACKSON (1928). Trans. I.E.S. (U.S.A.), 23, 1153. 


\begin{tabular}{|c|c|c|c|c|}
\hline \multicolumn{2}{|l|}{ Species } & Method & Mean ratio & Reference \\
\hline $\begin{array}{ll}7 \text { oxen } & \ldots \\
7 \text { dogs } & \ldots \\
2 \text { horses } & \ldots\end{array}$ & \begin{tabular}{l|}
$\cdots$ \\
$\cdots$ \\
$\cdots$
\end{tabular} & Urease-hypobromite & $\begin{array}{l}0.89 \\
0.82 \\
0.87\end{array}$ & Andresen (1921) \\
\hline $\begin{array}{l}\text { Horse } \\
\text { (pooled aque } \\
\text { and "typic } \\
\text { plasma) }\end{array}$ & ous & Urease & 0.94 & Duke-Elder (1927) \\
\hline 14 cats $\quad \ldots$ & $\ldots$ & Urease-gasometric & 0.75 & Adler (1933) \\
\hline 10 dogs, $3 \mathrm{rab}$ & bits & Aeration-titration & 0.70 & Walker (1933) \\
\hline 1 dog, 2 cats & & Conductimetric & 0.90 & Benham (1937) \\
\hline 21 cats $\ldots$ & ... & Aeration $\cdot$ Nesslerisation & $0: 73$ & $\begin{array}{l}\text { Moore, Scheie and } \\
\text { Adler (1942) }\end{array}$ \\
\hline 3 cats & $\cdots$ & Urease-Nesslerisation & 0.77 & $\begin{array}{l}\text { Scheie, Moore and } \\
\text { Adler (1943) }\end{array}$ \\
\hline 4 rabbits $\ldots$ & $\cdots$ & Aeration-titration & 0.66 & Kinsey and Grant (1942) \\
\hline 14 rabbits... & $\cdots$ & Urease-diffusion & 0.88 & $\begin{array}{l}\text { Kinsey and Robison } \\
(1946)\end{array}$ \\
\hline
\end{tabular}

If the blood-aqueous barrier were a simple semi-permeable membrane and the aqueous humour a dialysate or ultrafiltrate of the blood plasma, non-electrolytes such as urea would be equally partitioned per unit volume of water between the plasma and the aqueous humour. The existence of a urea deficit in the intraocular fluids indicates that either the nature of the blood-aqueous barrier or conditions within the eye are such as to modify this equilibrium, by :-

(a) selective secretion of urea across the barrier out of the eye (Adler, 1933).

(b) utilisation of urea within the eye, or by

(c) the existence of a continuous bulk outflow of aqueous humour from the eye so that the rate of drainage of urea from the eye exceeds the rate of entry of this substance into the eye (Kinsey and Grant, 1942.)

In the present paper a kinetic study of the permeability of the blood-aqueous and blood-vitreous barriers to urea has been undertaken, the aqueous/plasma concentration ratio has been redetermined, the mechanism of entry of urea into the eye studied and evidence of utilisation of this substance investigated. Its 
mode of exit from the eye will be considered in a subsequent paper.

\section{Part I-Kinétic Studies}

\section{THE PERMEABILITY TO UREA OF THE BLOOD-AQUEOUS BARRIER}

\section{Experimental}

In order to demonstrate that the blood-aqueous barrier is permeable to urea a kinetic study of the transport of this substance from the plasma to the intraocular fluids was undertaken.

The principle underlying this type of experiment was to maintain a constant high blood-urea by continuous intravenous injection of an isotonic solution into an animal under pentabarbitone (Nembutal) anaesthesia. The renal vessels were tied to prevent rapid excretion of the substance during the injection. One eye was enucleated immediately before the initial injection to give a value for the initial urea concentration within the eye: a sample of blood was simultaneously taken from the femoral artery. An initial injection of $20 \mathrm{mls}$. of 6 per cent. urea was then made within one minute to raise the blood urea rapidly to a figure of between 100 and $200 \mathrm{mg} . / 100 \mathrm{ml} . \mathrm{H}_{2} \mathrm{O}$, and further injections were made at intervals to maintain this high blood level since experience had shown that a stable level could be maintained by suitable boosts of urea solution. Samples of blood were removed at 10 minute intervals to check the constancy of this blood level. After a suitable interval (30 or 60 mins.) the other eye was enucleated and the final blood sample taken.

Fluids were removed from the eye as follows: aqueous was withdrawn from the anterior chamber, immediately after enucleation, by means of a clean, dry syringe; the vitreous body was obtained by freezing the enucleated eye in solid $\mathrm{CO}_{2}$, cutting the frozen eye round the equator, removing the frozen vitreous with forceps, thawing it and forcing it through a glass wool filter to break up its gel structure.

Urea in this and all subsequent experiments was determined by the ureasemicro-diffusion method of Conway (1946). This method was found to give consistent and accurate results with fluids of low and of high protein content, full recovery of added urea within 1 per cent. being obtained with plasma, aqueous and vitreous. The correction for plasma proteins was taken as 7 per cent. and all results are calculated as $\mathrm{mg}$. per $100 \mathrm{mls}$. of water. In all experiments it is assumed that the urea content of the aqueous of a pair of normal eyes is identical; determinations of the urea contents of the aqueous of the two eyes of a pair show that this assumpion is justified within 1 per cent.

\section{Results}

Detailed results are presented in Table I. These results have been calculated in terms of the permeability constants for aqueous humour $\left(\mathbf{K}_{\mathbf{A}}\right)$ and for the vitreous body $\left(\mathbf{K}_{\mathrm{V}}\right)$ as defined by Davson, and Quilliam (1940), where $\mathrm{K}=100 \log \frac{\left(\mathrm{S}-\mathrm{A}_{1}\right)}{\left(\mathrm{S}-\mathrm{A}_{2}\right)}-\frac{1}{\left(\mathrm{t}_{2}-\mathrm{t}_{1}\right)}$ $\left(S=\right.$ mean plasma urea concentration; $A_{1}=$ initial aqueous urea concentration at time $t_{1} ; A_{2}=$ final aqueous urea concentration at time $t_{2}$. Time is expressed in hours.)

The results show that the rate of penetration of urea into the aqueous is consistently higher than that into the vitreous : mean $\mathrm{K}_{\mathrm{A}}=11 \cdot 9$, mean $\mathrm{K}_{\mathrm{V}}=5 \cdot 4$. 
TABLE I

KINETIC STUDIES-RATE OF PENETRATION OF UREA INTO THE EYE (CAT)

(a) Penetration into the aqueous humour.

The permeability constant $K_{A}=100 \log \frac{\left(S-A_{1}\right)}{\left(S-A_{2}\right)} \cdot \frac{1}{\left(t_{2}-t_{1}\right)}$

(Concentration of urea expressed as $\mathrm{mg} / 100 \mathrm{~g} \mathrm{H}_{2} \mathrm{O}$ )

\begin{tabular}{l|r|r|r|r|r|r}
\hline Expt. & Blood 1 & Blood 2 & Aqueous 1 & Aqueous 2 & $\begin{array}{r}\text { Time } \\
\text { (mins. }\end{array}$ & $K_{A}$ \\
\hline 10 & 72.0 & 124.3 & 52.0 & 63.1 & 33 & 13.2 \\
12 & 58.0 & 94.2 & 45.6 & 50.8 & 32 & 9.4 \\
13 & 21.1 & 68.2 & 15.8 & 23.2 & 30 & 13.2 \\
15 & 70.1 & 169.8 & 57.0 & 67.8 & 30 & 8.7 \\
16 & 53.2 & 154.7 & 35.0 & 45.8 & 30 & 8.2 \\
17 & 48.3 & 85.9 & 54.2 & 61.0 & 30 & 20.8 \\
21 & 81.6 & 149.5 & 68.9 & 81.4 & 30 & 14.6 \\
23 & 45.6 & 114.0 & 35.1 & 67.5 & 122 & 13.2 \\
27 & 59.9 & 214.5 & 36.3 & 92.7 & 123 & 8.1 \\
28 & 55.6 & 131.7 & 43.5 & 55.4 & 33 & 11.2 \\
29 & 58.6 & 171.6 & 46.3 & 98.3 & 123 & 11.3 \\
30 & 88.3 & 189.7 & 90.4 & 127.1 & 120 & 113 \\
31 & 75.0 & 135.4 & 64.7 & 95.5 & 122 & 12.2 \\
& & & & & & \\
\hline
\end{tabular}

(b) Penetration into the vitreous body.

Permeability constant $K_{V}=100 \log \frac{\left(S-V_{1}\right)}{\left(S-V_{2}\right)} \cdot \frac{1}{\left(t_{2}-t_{1}\right)}$

(Concentration of urea expressed as $\mathrm{mg} / 100 \mathrm{~g} \mathrm{H}_{2} \mathrm{O}$ )

\begin{tabular}{|c|c|c|c|c|c|c|}
\hline Expt. & Blood 1 & Blood 2 & Vitreous 1 & Vitreous 2 & $\begin{array}{l}t_{2}-t_{1} \\
\text { mins. }\end{array}$ & $\mathbf{K}_{\mathbf{V}}$ \\
\hline $\begin{array}{l}23 \\
27 \\
28 \\
29 \\
30 \\
31\end{array}$ & $\begin{array}{l}91.2 \\
59.9 \\
55.6 \\
58.6 \\
88.3 \\
75.0\end{array}$ & $\begin{array}{l}225.6 \\
214.5 \\
131.7 \\
171.6 \\
180.7 \\
135.4\end{array}$ & $\begin{array}{l}69.5 \\
59.3 \\
24.9 \\
48.0 \\
69.5 \\
62.6\end{array}$ & $\begin{array}{r}113.0 \\
83.6 \\
29.3 \\
73.4 \\
94.6 \\
85.9\end{array}$ & $\begin{array}{r}122 \\
123 \\
33 \\
123 \\
120 \\
122\end{array}$ & $\begin{array}{l}7.0 \\
3.6 \\
3.5 \\
4.9 \\
5.5 \\
8.2\end{array}$ \\
\hline & . & & & . & Mean & $5.4 \pm 0.6$ \\
\hline
\end{tabular}

Part II-Static Studies

(a) The Aqueous/Plasma Ratio

Experimental

Fluids were removed simultaneously from animals under pentabarbitone anaesthesia' by the methods already described. 


\section{Plasma Uara Gongentrations of Unanaesthetised Rabbit} Samples taken at half-hour intervals.

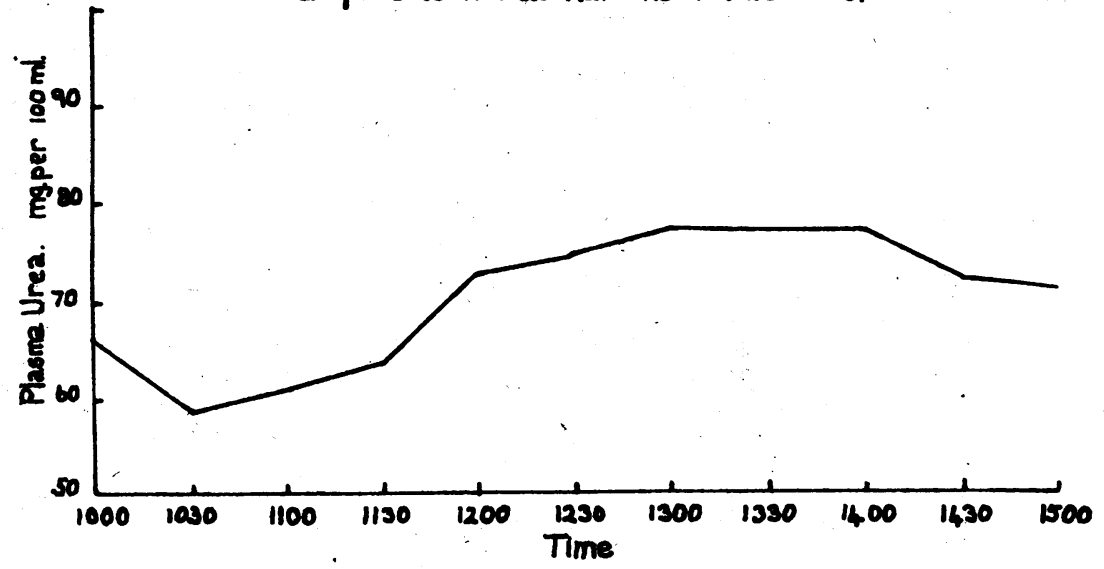

FIG. 1.

A study was also made of the fluctuations of the blood urea level in the unanaesthetised animal by taking blood samples at half-hourly intervals. The results, which are plotted in Fig. 1, show that in the course of 3 hours the urea concentration varied between 59 and $78 \mathrm{mg}$. per cent., a difference of 24 per cent., which will account for the wide scatter of the experimental ratios since changes of urea concentration in the aqueous will lag behind the changes in the blood.

TABLE II

THE DISTRIBUTION OF UREA BETWEEN BLOOD PLASMA, AQUEOUS HUMOUR AND VITREOUS BODY OF CATS

(Concentration of urea expressed as $\mathrm{mg} / 100 \mathrm{~g} \mathrm{H}_{2} \mathrm{O}$ )

\begin{tabular}{r|c|c|c|c|c}
\hline Expt. & Plasma & Aqueous & Vitreous & $\frac{\text { Aqueous }}{\text { Plasma }}$ & $\frac{\text { Vitreous }}{\text { Plasma }}$ \\
\hline & & & & & \\
9 & 57.7 & 45.7 & 51.4 & 0.80 & 0.89 \\
10 & 72.0 & 52.0 & 44.1 & 0.72 & 0.61 \\
12 & 58.0 & 45.6 & 44.9 & 0.78 & 0.77 \\
13 & 21.1 & 15.8 & - & 0.75 & - \\
15 & 70.1 & 570 & - & 0.81 & - \\
16 & 53.2 & 35.0 & - & 0.66 & - \\
18 & 32.6 & 22.6 & - & 0.69 & - \\
20 & 30.2 & 25.4 & - & 0.84 & - \\
21 & 81.6 & 68.9 & - & 0.84 & - \\
23 & 45.6 & 35.1 & 347 & 0.77 & 0.76 \\
25 & 47.1 & 35.0 & 34.2 & 076 & 0.73 \\
27 & 59.9 & 36.3 & - & 0.61 & - \\
28 & 55.6 & 43.5 & - & 0.78 & - \\
29 & 58.6 & 46.3 & 48.0 & 0.79 & 0.82 \\
31 & 75.0 & 64.7 & 62.6 & 0.86 & 0.83 \\
\hline & & & & & \\
\hline
\end{tabular}


THE DISTRIBUTION OF UREA BETWEEN THE BLOOD PLASMA AND AQUEOUS HUMOUR OF RABBITS

\begin{tabular}{l|c|c|c}
\hline Expt. & Plasma & Aqueous & Aqueous/Plasma \\
& & & \\
\hline & 40.4 & 31.0 & 0.76 \\
45 & 74.8 & 59.9 & 0.80 \\
47 & 48.7 & 32.8 & 0.68 \\
48 & 54.0 & 40.5 & 0.74 \\
50 & 65.8 & 52.2 & 0.79 \\
51 & 31.0 & 25.4 & 0.79 \\
53 & 48.5 & 34.0 & 0.70 \\
54 & 52.0 & 37.4 & 0.72 \\
55 & 71.9 & 50.3 & 0.74 \\
57 & 66.5 & 52.5 & 0.79 \\
58 & & & \\
\hline
\end{tabular}

\section{Results}

The distribution of urea between aqueous humour, vitreous body and plasma is shown in Table II. The existence of a deficit of urea in the intra-ocular fluids compared with the plasma water is confirmed. The mean aqueous/plasma ratio of 15 cats was found to be 0.76 , that of 10 rabbits 0.75 ; the mean vitreous/plasma ratio of 7 cats was $\mathbf{0 . 7 7}$. Infinity values obtained by maintaining the blood concentration at a high level for many hours showed that apparent equilibrium between the two fluids had been reestablished at the end of $3 \frac{1}{2}$ hours $>$ this infinity ratio had a mean value of 0.73 .

\section{(b) THE UTILISATION OF UREA WiTHIN THE EYE}

Urea is regarded as the end-product of nitrogen catabolism in the mammal, and no evidence has so far been adduced that this substance plays any part in the synthetic processes of the body. The possibility that the difference in the urea concentration of blood and intra-ocular fluids may be due to utilisation within the eye by the metabolic activities of the lens, ciliary body or retina was nevertheless explored by both in vitro and in vivo experiments.

\section{IN VITRO EXPERIMENTS}

Study of the exchange between the lens and its environment was made with lenses excised from the enucleated eyes of rabbits and cats. 
Assuming (1) that urea enters the eye by a process of diffusion, secretion, or filtration, not yet fully elucidated, and is removed by drainage, (2) that the urea concentration of the fluid crossing the blood-aqueous barrier is identical with that of plasma, (3) that the drainage rate from the anterior chamber is $4 \mathrm{cmm}$. per min. (Kinsey and Grant, 1942; preliminary results of studies in this laboratory indicate that the rate is much higher in the cat), and (4) that the blood urea concentration is $40 \mathrm{mg}$. per cent., that the aqueous/plasma ratio is 0.75 , and (5) that the volume of aqueous humour in the cat is $1.0 \mathrm{ml}$, then the quantity of urea entering the eye per hour is

$$
\left(\frac{40}{100} \times \frac{4}{1,000} \times 60\right) \mathrm{mg} .
$$

and the quantity leaving the eye per hour is

$$
\left(\frac{30}{100} \times \frac{4}{1,000} \times 60\right) \mathrm{mg} \text {. }
$$

It follows that the quantity of urea removed per hour from the aqueous humour between its entrance to, and its exit from, the eye will be

$$
\frac{(10 \times 4 \times 60)}{10^{5}} \mathrm{mg} \cdot=0.024 \mathrm{mg} \cdot \text { per hour. }
$$

If the metabolic activity of the lens is the factor responsible for the removal of urea from the aqueous so as to account for an aqueous/plasma ratio of 0.75 , then the surviving lens immersed. in a physiological medium containing urea should remove urea from this medium at a constant rate of $0.024 \mathrm{mg}$. per hour.

\section{Experimental}

The lens was removed from the excised eye, dried on filter paper and weighed, the whole procedure occupying less than 10 minutes. It was then transferred to a specimen tube containing fresh ox aqueous from eyes obtained from a slaughter-house and kept on ice until used; to this medium at $\mathrm{pH} 7.4$ urea was added to give the required concentration. In the first set of experiments the lenses were incubated for 24 hours at $0^{\circ} \mathrm{C}$, in subsequent experiments the incubation time was 2 hours at $37^{\circ} \mathrm{C}$; there is no obvious criterion of viability of a lens, and it was considered probable that the survival time of an isolated lens even in a physiological medium is a matter of a few hours only.

The urea concentration of this ox aqueous medium was fortified by added urea so that samples containing approximately 20,50 and $80 \mathrm{mg}$. per cent. were obtained: the $2 \mathrm{ml}$. quantities employed in each experiment would thus contain $0.4,1.0$ and $1.6 \mathrm{mg}$. of urea respectively. After incubation for the required time the urea concentration of the medium and of a blank control of the same solution was determined. 
TABLE III

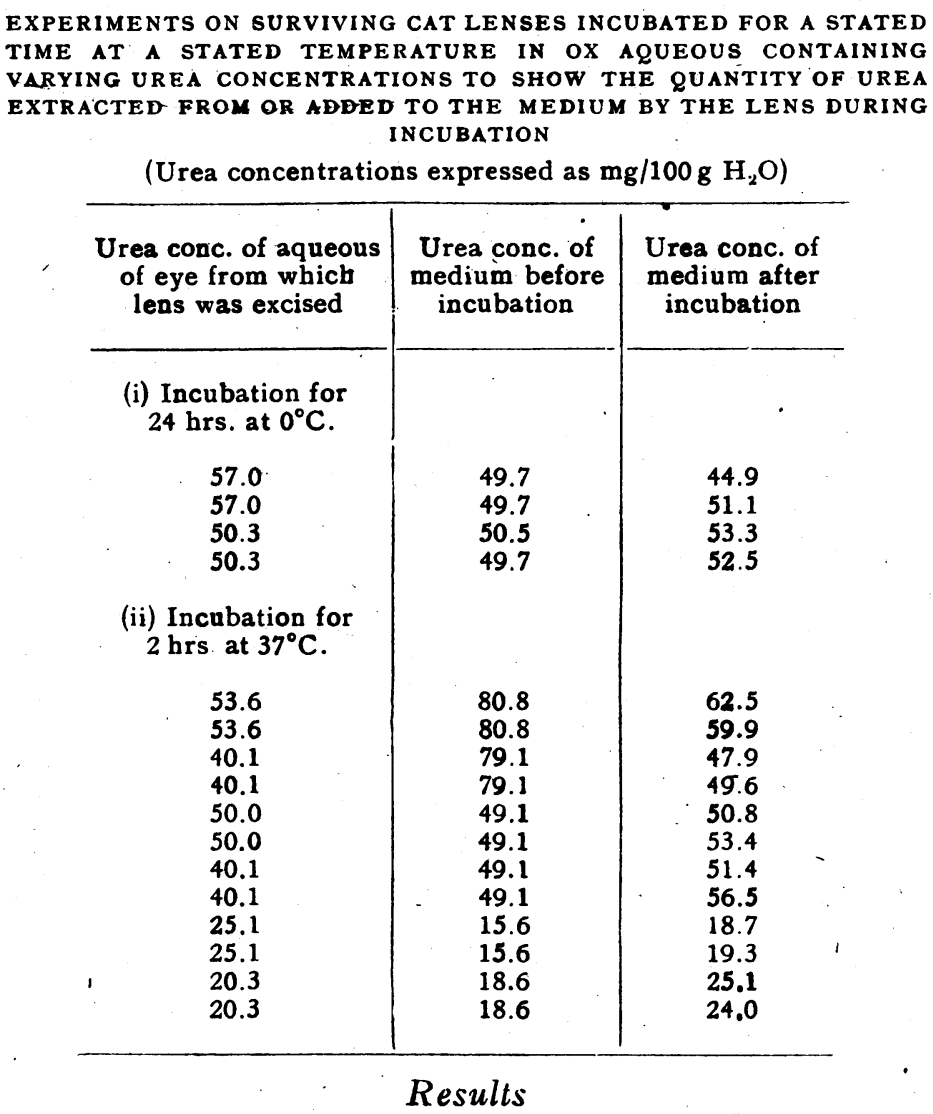

Detailed results are presented in Table III. They show that such differences as exist in the urea concentration of the medium before and after immersion of the lens in it for two hours can be accounted for by diffusion of the substance from a medium with higher, to a medium with lower concentration of urea; thus urea is removed by the lens from the medium when this contains a high concentration of the substance, but is added to the medium when the urea concentration of the medium is below that of the aqueous with which the lens was previously in equilibrium.

IN VIVO EXPERIMENTS

(i) ON THE EXCISED EYE

\section{Experimental}

The question of the utilisation of urea by the structures within the eye was further investigated by removing both eyes from the animal (rabbit) within as short a space of time as possible, evacuating the aqueous from one of the pair 
immediatelv and determining the urea concentration of this fluid. The fluid of the other eye was evacuated after it had been kept at $37^{\circ} \mathrm{C}$. for two hours and its urea concentration determined. Any difference in the urea concentration of the aqueous in the-two eyes would indicate utilisation of urea within the eye by such vital processes as continued to function.

TABLE IV

EXPERIMENTS ON THE EXCISED EYE SHOWING THE UREA CONCENTRATION OF THE AQUEOUS HUMOUR OF A PAIR OF EYES, ONE AT THE TIME OF EXCISION AND THE OTHER TWO HOURS AFTER EXCISION. (RABBITS).

(Urea concentration expressed as $\mathrm{mg} / 100 \mathrm{~g} \mathrm{H}_{2} \mathrm{O}$ )

Urea conc. of aqueous in two eyes of a pair

\begin{tabular}{c|c}
\hline $\begin{array}{c}\text { (i) at time of } \\
\text { excision }\end{array}$ & $\begin{array}{c}\text { (ii) } 2 \text { hrs. after } \\
\text { excision }\end{array}$ \\
\hline 65.2 & 64.0 \\
45.8 & 44.0 \\
56.5 & 54.9 \\
44.0 & 43.5 \\
49.2 & 48.0 \\
\hline
\end{tabular}

\section{Results}

Results are presented in Table IV : these show that the differences in concentration initially and at the end of the two hours are too small to account for a utilisation sufficient to lower the aqueous urea concentration to 25 per cent. below that of blood. The volume of - a rabbit's aqueous is about $0.25 \mathrm{ml}$. so that a difference of $1.2 \mathrm{mg}$. per cent. represents a loss of only 0.0015 mg. per hour: the theoretical rate to achieve the 25 per cent. deficit is $0.006 \mathrm{mg}$. per hour.

\section{(ii) EXPERIMENTS ON THE APHAKIC ANIMAL}

\section{Experimental}

If the lens is the factor responsible for removing urea from the intra-ocular fluids, the aphakic eye will show an aqueous/plasma ratio which approaches unity.

The lens of one eye was removed in a series of five rabbits by the standard surgical procedure for extra-capsular extraction. After an interval of six weeks to allow for complete healing, fluids were withdrawn from both eyes simultaneously and a blood sample obtained from the aural vein. Utilisation of urea by the lens would result in a lower concentration of urea in the unoperated eye compared with the aphakic eye.

\section{Results}

Results presented in Table $\mathrm{V}$. show that the unoperated eye consistently contained a slightly lower urea concentration than did the aphakic eye. The mean aqueous/plasma ratio of the 
TABLE V

EXPERIMENTS ON THE APHAKIC EYE. UREA CONCENTRATION OF AQUEOUS HUMOUR IN THE NORMAL AND THE APHAKIC EYE OF A PAIR. (RABBITS).

(Concentration of urea expressed as $\mathrm{mg} / 100 \mathrm{~g} \mathrm{H}_{2} \mathrm{O}$ )

\begin{tabular}{c|c|c|c|c}
\hline Plasma & $\begin{array}{c}\text { Normal } \\
\text { eye }\end{array}$ & $\frac{\text { Aqueous }}{\text { Plasma }}$ & $\begin{array}{c}\text { Aphakic } \\
\text { eye }\end{array}$ & $\frac{1 \text { Aqueous }}{\text { Plasma }}$ \\
\hline 33.3 & 25.4 & 0.76 & 27.7 & 0.83 \\
71.2 & 55.3 & 0.77 & 57.1 & 0.80 \\
46.3 & 36.6 & 0.79 & 37.9 & 0.82 \\
89.8 & 68.9 & 0.76 & 71.2 & 0.80 \\
61.0 & 44.5 & 0.73 & 47.5 & 0.78 \\
\hline
\end{tabular}

normal eye is 0.76 , that of the aphakic eye is 0.81 ; although the aqueous/plasma ratio is raised in the aphakic eye it has not become sufficiently close to unity for utilisation of urea by the lens to be the explanation of the urea deficit within the eye.

\section{Part III-The rôle of ultrafiltration in the formation of the intra-ocular fluids}

\section{(In collaboration with E.'Bárány*)}

Kinsey and Grant (1942) conclude from their study of aqueous humour dynamics that electrolytes are secreted across the bloodaqueous barrier but that water and non-electrolytes enter the eye by ultra-filtration. For ultra-filtration to separate a fluid from the blood against the colloid osmotic pressure of the blood (about $25 \mathrm{~mm}$. $\mathrm{Hg}$ ) and against the intra-ocular pressure $(25-30 \mathrm{~mm} . \mathrm{Hg})$ a capillary pressure greater than $50-55 \mathrm{~mm}$. $\mathrm{Hg}$ would be required; the greater the capillary pressure above this level the greater will be the rate of ultra-filtration. In the absence of any compensatory mechanism stabilising capillary pressure (and observations by Bárány of the capillaries of a rabbit's ear have revealed no such mechanism) any alteration of arterial pressure will materially affect the driving force across the membrane and, therefore, the rate of ultra-filtration. A measure of the part played by ultra-filtration can thus be obtained experimentally by variation of this pressure factor.

Reduction of the local capillary pressure and of the intra-ocular pressure can be produced by carotid ligation. As previously shown by Bárány $(1946,1947 a)$ ligation of one common carotid in rabbits causes a fall of blood pressure, as measured in the

\footnotetext{
* Physiological Institute, University of Uppsala.
} 
central artery of the ear, of the order of $30-40$ per cent. and a fall of intra-ocular pressure of $15-20$ per cent. on the affected side for a period of at least 24 hours. If ultra-filtration is a significant factor such a fall of blood pressure could be expected to cause a considerable reduction in the rate of aqueous flow and hence in the rate of entry of water into the eye, an effect which should result in a rise in the urea concentration of the aqueous. Unilateral carotid ligation was accordingly performed upon a series of 10 rabbits, and the urea concentrations of the aqueous of the normal and affected eye compared.

\section{Experimental}

The common carotid artery was tied on one side in rabbits under pentabarbitone anaesthesia, the van Leersum loop technique being employed. After 24 hours, when the animals had completely recovered, they were killed by decapitation and the aqueous removed from both eyes as quickly as possible. Arterial blood was collected from the neck.

\section{TABLE VI}

THE EFFECT OF REDUCING THE ARTERIAL PRESSURE BY CAROTID OCCLUSION UPON THE UREA CONCENTRATION OF THE AQUEOUS HUMOUR OF RABBITS.

(Concentration of urea expressed as $\mathrm{mg} / 100 \mathrm{~g} \mathrm{H}_{2} \mathrm{O}$ ).

\begin{tabular}{|c|c|c|c|c|c|c|c|}
\hline Expt. & $\begin{array}{l}\text { Side } \\
\text { tied }\end{array}$ & Plasma & $\begin{array}{l}\text { Aqueous } \\
\text { on untied } \\
\text { side }\end{array}$ & $\begin{array}{l}\text { Aqueous } \\
\text { on tied } \\
\text { side }\end{array}$ & $\begin{array}{c}\text { Difference } \\
\text { Tied - } \\
\text { Untied }\end{array}$ & $\begin{array}{l}\text { Duplicates } \\
\text { agreed } \\
\text { within }\end{array}$ & $\begin{array}{c}\begin{array}{c}\text { Ratio } \\
\text { Aqueous }\end{array} \\
\text { Plasma }\end{array}$ \\
\hline $\begin{array}{l}45 \\
47 \\
48 \\
50 \\
51 \\
53 \\
55 \\
55 \\
57 \\
58\end{array}$ & $\begin{array}{l}\text { L } \\
\text { L } \\
\text { L } \\
\text { L } \\
\text { L } \\
\text { R } \\
\text { R } \\
\text { R } \\
\text { R } \\
\text { R }\end{array}$ & $\begin{array}{l}80.9 \\
74.8 \\
48.7 \\
54.0 \\
65.8 \\
31.9 \\
48.5 \\
52.0 \\
71.9 \\
66.5\end{array}$ & $\begin{array}{l}62.1 \\
59.9 \\
32.8 \\
40.5 \\
52.2 \\
25.4 \\
34.0 \\
37.4 \\
50.3 \\
52.5\end{array}$ & $\begin{array}{l}69.3 \\
66.6 \\
37.8 \\
39.5 \\
48.0 \\
26.6 \\
30.6 \\
38.4 \\
53.6 \\
51.4\end{array}$ & $\begin{array}{l}+7 \mathrm{mg} \% \\
+7 \mathrm{mg} \% \\
+5 \mathrm{mg} \% \\
+1 \mathrm{mg} \% \\
+1 \mathrm{mg} \% \\
+3 \mathrm{mg} \% \\
+1 \mathrm{mg} \% \\
+3 \mathrm{mg} \% \\
-1 \mathrm{mg} \%\end{array}$ & $\begin{array}{l}2 \% \\
2 \% \\
3 \% \\
1 \% \\
2 \% \\
3 \% \\
1 \% \\
2 \% \\
2 \% \\
.3 \%\end{array}$ & $\begin{array}{l}0.76 \\
0.80 \\
0.68 \\
0.74 \\
0.79 \\
0.79 \\
0.70 \\
0.72 \\
0.74 \\
0.79\end{array}$ \\
\hline & & & & & & Mean & $0.75 \pm 0.02$ \\
\hline
\end{tabular}

\section{Results}

Results are presented in Table VI. These show that lowering the systemic blood pressure by carotid ligation has no significant influence on the concentration of urea in the aqueous; the ratio of concentrations of aqueous (occluded) to aqueous (control) $=1.028 \pm 0.025$. 


\section{Discussion}

The blood-aqueous barrier has been shown by kinetic studies to be permeable to urea although the rate of penetration of this substance into the eye is slower than that of water, of other nonelectrolytes such as ethyl alcohol, glucose, or glycerol and corresponds with that of other nitrogenous substances such as creatinine, glycine or alanine. The permeability constants of these substances are compared in Table VII.

This relatively slow rate of penetration is surprising in view of the rapidity with which urea penetrates membranes in other parts of the body, e.g., it penetrates the red cell envelope 35 times faster than does glycerol and yet its apparent rate of entry into the eye is' only half that of glycerol. If entry into the eye occurred by

TABLE VII

\begin{tabular}{|c|c|c|c|c|}
\hline Substance & $\mathbf{K}_{\mathbf{A}}$ & $\mathbf{K}_{\mathbf{v}}$ & Species & Reference \\
\hline Water & c. 300 & - & Rabbit & $\begin{array}{l}\text { Recalculated from Kinsey, Grant } \\
\text { and Cogan (1942). }\end{array}$ \\
\hline Ethyl alcohol & c. 90 & - & Rabbit & Recalculated from Palm (1947). \\
\hline Glucose & 34 & 11 & Cat & Davson and Duke-Eider (1948). \\
\hline Glycerol & 22 & 5 & Cat & $\begin{array}{l}\text { Davson, Duke-Elder, Maurice, Ross } \\
\text { and Woodin (in press). }\end{array}$ \\
\hline Creatinine ... & 14 & 1.9 & Cat & Ibid. \\
\hline Glycine & 13.5 & 1.0 & Cat & Ibid. \\
\hline Alanine & 12.7 & 0.8 & Cạt & Ibid. \\
\hline Urea ... & 11.9 & 5.4 & Cat & - \\
\hline
\end{tabular}

ultrafiltration across a semipermeable membrane through large water-filled pores, non-electrolytes should have a permeability constant which is proportional to the square root of their molecular weights (Davson and Danielli, 1943). Davson and Duke-Elder's (1948) studies of the permeability constants of carbohydrates suggest that these substances pass into the eye at rates inversely proportional to their molecular size. The urea molecule is only one-third as large as that of glucose and yet the glucose molecule enters the eye three times as fast as urea, a fact suggesting that in the case of urea some activity other than a process of ultrafiltration 
is involved. Paracentesis of aqueous from the anterior chamber temporarily deranges this selective permeability of the barrier so that the urea concentration of the reformed "secondary" aqueous is at first equal to that of the plasma water, slowly falling to normal within the succeeding 24 hour's.

The blood-vitreous barrier has been found to be even less permeable to urea than is the blood-aqueous barrier, the respective permeability constants being 5.4 and 11.9 .

Re-determination of the aqueous/plasma and vitreous/plasma concentration ratios has confirmed previous observations that a deficit of the order of 20 per cent. exists between the intra-ocular fluids and the plasma water; an aqueous/plasma ratio of 0.76 was found in the cat and of 0.75 in the rabbil : the vitreous/plasma ratio was 0.77 in the cat.

The existence of this deficit in the intra-ocular fluids might indicate that urea was entering the eye by ultrafiltration and was being removed by entering into the metabolism of the lens or other structures within the eye. This possibility has been examined by a comparison of the aqueous/plasma ratios of the normal and the aphakic eye in rabbits, by in vitro studies of the lens and also of the excised eye, but no evidence for any utilisation of urea has been found.

The respective contributions of ultrafiltration and secretion to the formation of the aqueous have been studied by a method due to Bárány $(1947 b)$. If ultrafiltration were an important mechanism in aqueous formation then, following Kinsey and Grant's (1942) hypothesis, reduction in systemic blood pressure by unilateral carotid occlusion would cause a reduction in the rate of ultrafiltration which would show up as a rise in the urea concentration on the affected side. Such a rise cannot be demonstrated experimentally, from which it has been inferred that ultrafiltration plays little part in the formation of the aqueous humour.

These results are in agreement with the findings of Bárány $(1947 b)$ who found that reduction of blood pressure had no effect. upon the rate of entry on $\mathrm{Na}^{24}$ into the aqueous. Bárány (1947c) later found that lowering the blood pressure likewise had no effect on the osmotic pressure of the aqueous such as would be expected to occur if ultrafiltration were playing a dominant part in aqueous formation.

These results suggest that some mechanism is present at the barrier to regulate the entry of fluid into the eye so as to maintain the aqueous flow constant irrespective of the systemic blood pressure.

The data presented in this paper thus show that the bloodaqueous barrier offers considerable resistance to the entry of urea 
into the eye and that its rate of penetration is independent of the systemic blood pressure; the evidence obtained suggests that urea enters the eye by some process other than simple ultra-filtration.

\section{Summary}

(1) The urea concentration in the aqueous humour and the vitreous body has been found to be respectively 76 per cent. and 77 per cent. of that of the plasma water.

(2) The rate of penetration of urea into the aqueous and vitreous has been measured and the corresponding permeability constants calculated. These show that penetration into the aqueous is twice as rapid as into the vitreous and indicate that the blood-aqueous and blood-vitreous barriers offer considerable resistance to the passage of urea from the blood to the intra-ocular fluids.

(3) The urea deficit within the eye is not due to utilisation by structures within the eye.

(4) The rate of penetration into the aqueous has been shown to be independent of the systemic blood pressure and the evidence presented suggests that the substance is transferred across the blood-aqueous barrier by a process other than simple ultrafiltration.

I am indebted to Sir Stewart Duke-Elder and Dr. Hugh Davson for their interest and advice.

\section{REFERENCES}

ANDRESEN, K. L. G. (1921).-Biochem. Zeitschr., 116, 266.

AdLER, F. H. (1933). -Arch. of Ophthal., 10, 11.

BÁRÁNY, E. H. (1946).-Acta Ophthal., 24, 337.

- (1947a).-Ibid., 25, 81 .

- (1947b).-Acta Physiol. Scand., 13, 55.

- (1947c).-Ibid., 13, 81.

BENHAM, G. H. (1937). -Biochem. J., 31, 1157.

CONWAY, E. J. (1946).-Microdiffusion analysis and volumetric error. Second edition. London.

Davson, H. and DANIELli, J. F. (1943). - The permeability of natural membranes. Cambridge University Press. and Duke-Elder, W. S. (1948).-J. Physiol., 107, 141.

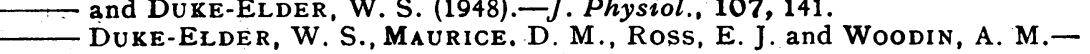
lbid., in press.

- a and QuilliaM, J. P. (194C).-Ibid., 98, 141.

DUKE-ELDER, W. S. (1927).-Biochem. J., 21, 66.

Kinsey, V. E. and GRANT, W. M. (1942).-J. Gen. Physiol., 26, 119, 131. and CogAN, D. G. (1942).-Arch. of Ophthal., 27, 242. and RoBison, P. (1946).-J. Biol. Chem., 162, 325.

MOORE, E., SCHEIE, H. G. and ADLER, F. H. (1942).-Arch. of Ophthal., $27,317$. PALM, E. (1947).-Acta Ophthal., 25, 139.

SCHEIE, H. G., MOORE, E. and ADLER, F. H. (1943).-Arch. of Ophthal., 30, 70. WALKER, A. M. (1933).-J. Biol. Chem., 101, 269. 